NOTE

\title{
Considerations on the toxigenic nature and prey sources of Phalacroma rotundatum
}

\author{
Sonsoles González-Gil ${ }^{1,2, *, * *}$, Gemita Pizarro ${ }^{1,3, * *}$, Beatriz Paz ${ }^{1,4}$, \\ Lourdes Velo-Suárez ${ }^{1,5}$, Beatriz Reguera ${ }^{1}$ \\ ${ }^{1}$ Instituto Español de Oceanografía, Centro Oceanográfico de Vigo, Aptdo. 1552, 36200 Vigo, Spain \\ ${ }^{2}$ Present address: Instituto Español de Oceanografía, Corazón de María 8, 28002 Madrid, Spain \\ ${ }^{3}$ Present address: Instituto de Fomento Pesquero-CEQUA, Enrique Abello 0552, Casilla 101, Punta Arenas, Chile \\ ${ }^{4}$ Present address: CACTI, Universidade de Vigo, Campus Lagoas-Marcosende 15, 36310 Vigo, Spain \\ ${ }^{5}$ Present address: Woods Hole Oceanographic Institution, 266 Woods Hole Rd, Woods Hole, MA 02543, USA
}

\begin{abstract}
The heterotrophic dinoflagellate Phalacroma rotundatum (Claparède \& Lachman) Kofoid \& Michener is considered a toxic species, but there is controversy about its toxigenic nature. In the present study, about one-third of the toxin analyses done with liquid chromatography-mass spectrometry (LC-MS) of $P$. rotundatum specimens picked from field populations in Galicia (NW Spain) between 2003 and 2005 revealed traces of lipophilic toxins - okadaic acid (OA) and/or dinophysistoxin-2 (DTX2) and/or pectenotoxin-2 (PTX2) (if any) - that mimicked the toxin profile of cooccurring toxigenic mixotrophic species of Dinophysis (D. acuminata, D. acuta, and D. caudata). Thus, during the period of study, $P$. rotundatum was never a relevant contributor to diarrhetic shellfish poisoning (DSP) toxins contaminating shellfish resources in Galicia. Observations of phycoerythrin-like autofluorescence in P. rotundatum and in its co-occurring potential ciliate prey - Tiarina cf. fusus led to the suspicion that $P$. rotundatum had taken up toxins by feeding on this ciliate prey that had previously fed on Dinophysis spp. Nevertheless, toxins in P. rotundatum specimens with orange autofluorescence were under detection levels, and the source of these orange pigments may be a prey different from Dinophysis spp. (e.g. Myrionecta spp.). New results here add evidence to suggest that $P$. rotundatum does not produce toxins de novo, but acts as a vector from toxin-containing prey to shellfish, and that M. rubra may be one of its potential ciliate prey. Conclusive testing of these hypotheses is now under investigation with laboratory cultures of Dinophysis and Phalacroma spp. and M. rubra.
\end{abstract}

KEY WORDS: Phalacroma rotundatum - Dinophysis spp. · Diarrhetic shellfish poisoning - DSP · Pectenotoxins $\cdot$ PTX $\cdot$ Lipophilic shellfish toxins

Resale or republication not permitted without written consent of the publisher

\section{INTRODUCTION}

Phalacroma rotundatum (Claparède \& Lachman) Kofoid \& Michener (= Dinophysis rotundata) is a heterotrophic dinoflagellate widely distributed in cold to warm waters (Hallegraeff \& Lucas 1988, Larsen \& Moestrup 1992, Jensen \& Daugbjerg 2009) and usually reported to occur at low cellular densities $\left(1 \times 10^{2}\right.$ to $2 \times$
$10^{2}$ cells $^{-1}$ ). This species is included in the list of toxinproducing dinophysoids (Zingone \& Larsen 2011) on the basis of one single high-performance liquid chromatography analysis with fluorescence detection (HPLC-FD) of cells, isolated from Japanese coastal waters, which revealed a high cellular content (101 pg cell $^{-1}$ ) of dinophysistoxin-1 (DTX1) (Lee et al. 1989). Different authors were not able to detect any lipophilic 
toxins either in dense net-hauls where $P$. rotundatum was not accompanied by other Dinophysis spp. (Cembella 1989, Caroppo et al. 1999) nor in single-cell isolates analyzed by liquid chromatography coupled to mass spectrometry (LC-MS) (Suzuki et al. 2009). In contrast, Miles et al. (2004) showed traces of lipophilic toxins in P. rotundatum cells picked from net-haul samples dominated by other Dinophysis spp. The possibility of false positives - due to interfering false peaks deriving from fluorescence reagents and biological matrices - has been suggested to explain discrepancies among different cellular toxin content observed in the same species using different analytical methods (Suzuki et al. 2009). An intriguing question concerning the mixotrophic species of Dinophysis has been whether the toxins are synthesized de novo or are derived from their prey. Recently, de novo production of okadaic acid (OA) derivatives and pectenotoxins in the mixotroph $D$. acuminata and the lack of toxins in its prey — the ciliate Myrionecta rubra — has been proved in laboratory cultures (Kamiyama \& Suzuki 2009).

Phalacroma rotundatum was observed to feed on tintinnid ciliates (Elbrächter 1991) and to become replete of digestive vacuoles after feeding on laboratory cultures of the ciliate Tiarina fusus (Hansen 1991). Jacobson \& Andersen (1994) observed vacuoles in field specimens of $P$. rotundatum under light (differential interference contrast [DIC]) microscopy. However, toxins were not analyzed by these previous authors.

In the present study, the toxigenic nature of Phalacroma rotundatum is questioned on the basis of LCMS analyses of single-cell isolates of this species and co-occurring Dinophysis spp. collected in the Galician Rías Baixas (NW Spain) between 2003 and 2007. It is proposed that $P$. rotundatum does not produce toxins de novo but acts as a vector of diarrhetic shellfish poisoning (DSP) toxins and pectenotoxins accumulated in its ciliate prey that had previously fed on co-occurring toxin-producing Dinophysis spp.

\section{MATERIALS AND METHODS}

Plankton samples. Plankton samples were collected either by vertical net hauls $(20 \mu \mathrm{m}$ mesh; 0 to $20 \mathrm{~m}$ depth) or by size-fractioning (20 to $77 \mu \mathrm{m}$ ) through a set of superimposed meshes, between spring and autumn, 2003, 2005, and 2007, at one station from Ría de Pontevedra (Galicia, NW Spain) (Fig. 1) on board the RV 'J. M. Navaz'. Back in the laboratory, in vivo autofluorescence of Dinophysis spp. was observed under a Nikon Eclipse TE2000-S inverted microscope with epifluorescence, using blue-light excitation (excitation 450 to $490 \mathrm{~nm}$, emission $520 \mathrm{~nm}$ long pass) and a short-pass filter set specific to select phycoerythrin fluorescence

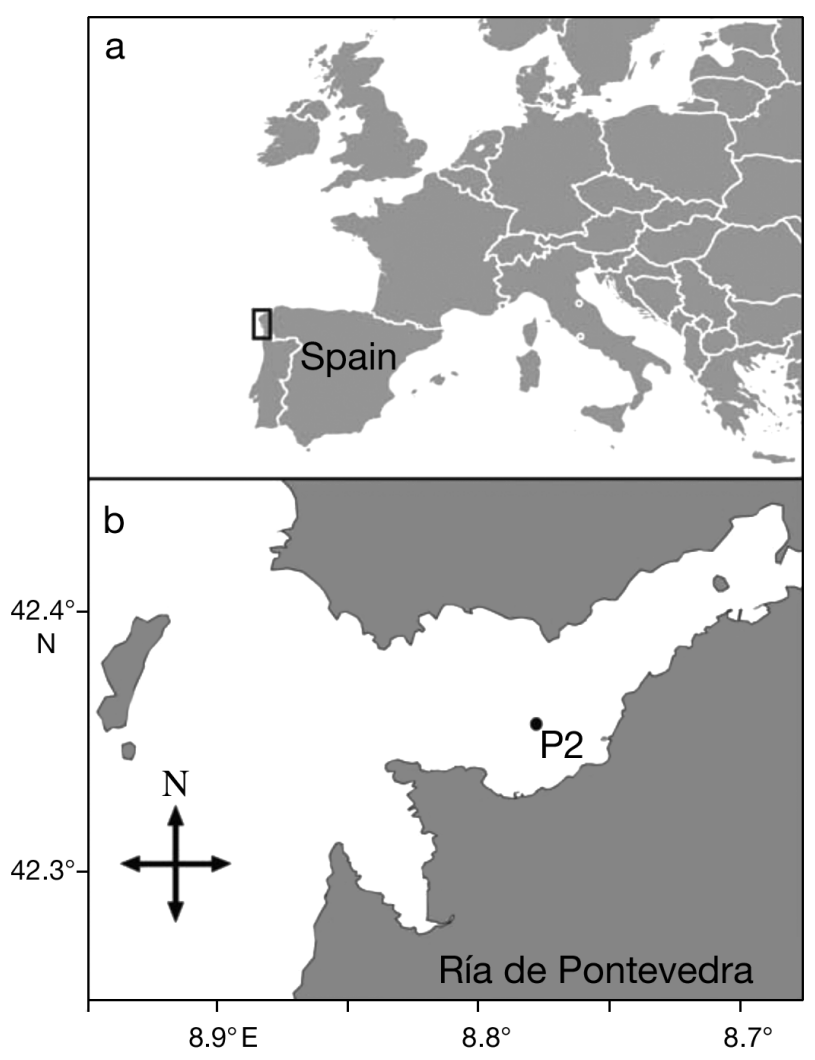

Fig. 1. Location of (a) Ría de Pontevedra (NW Spain) and (b) sampling station (P2)

(excitation $546 \mathrm{~nm}$, emission $585 \mathrm{~nm}$ short pass). Nuclear staining was carried out with the DNA-specific fluorochrome SYBR Green I (Molecular Probes). Digitized micrographs (100x and 400× magnification) were taken with a Nikon D70 camera coupled to the microscope.

Cell isolation and extractions for toxin analysis. Phalacroma rotundatum cells were isolated one by one by micromanipulation with a microcapillary pipette, transferred 2 to 3 times through sterile seawater, and placed into $1.5 \mathrm{ml}$ Eppendorf tubes with $500 \mu \mathrm{l}$ methanol. Cells were sonicated for $1 \mathrm{~min}$, another $500 \mu \mathrm{l}$ of methanol was added, and the extract was frozen at $-20^{\circ} \mathrm{C}$. Prior to analysis, extracts were dried at $40^{\circ} \mathrm{C}$ (Speed Vac, Savant Instruments), re-suspended in $150 \mu \mathrm{l}$ methanol, and filtered $(0.45 \mu \mathrm{m}$ filters, Gelman Nylon Acrodisc $13 \mathrm{~mm}$ ) before injection into the LC-MS system.

Toxin analysis by LC-MS. Chromatographic separation was performed on a Thermo Finnigan Surveyor with a Waters XTerra C18 column $5 \mu \mathrm{m}(2.1 \times 150 \mathrm{~mm})$ at $35^{\circ} \mathrm{C}$. The mobile phase consisted of $2 \mathrm{mM}$ ammonium acetate at pH 5.8 (solution A) and $100 \%$ methanol

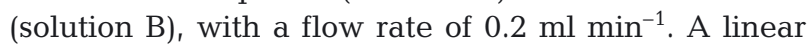
gradient elution from 60 to $100 \%$ of solution B was run for $20 \mathrm{~min}$ and re-equilibration with $60 \%$ of solution B for 8 min was used. The sample injection volume was 
variable (5 to $20 \mu \mathrm{l}$ ) depending on toxin concentration. The spectral measurements were performed using an ion-trap mass spectrometer (Thermo Finnigan LCQAdvantage) equipped with an electrospray ionization interface (ESI) under the same operating conditions described in Pizarro et al. (2009). Calibration and quantification was performed using OA and pectenotoxin-2 (PTX2) certified reference standards (National Research Council of Canada) and quantified dinophysistoxin-2 (DTX2) $\left(6 \mu \mathrm{g} \mathrm{ml}^{-1}\right)$ reference material provided by P. Hess (IFREMER, Nantes, France).

\section{RESULTS AND DISCUSSION}

Phalacroma rotundatum was present in very low cell densities $\left(<10^{2}\right.$ cells $\left.\mathrm{l}^{-1}\right)$ and co-occurred with more abundant species of Dinophysis, and only on 8 occasions were there enough cells in the plankton concentrate to carry out single-cell isolation of $P$. rotundatum. Five out of 11 picked-cell samples presented detectable levels of lipophilic shellfish toxins (Table 1). Cells isolated from aliquots of the same plankton concentrate, or from plankton samples collected $1 \mathrm{~d}$ apart, showed different qualitative results (presence or absence and toxin profile). The selected ion chromatograms and mass spectra of the standards and reference material for OA/DTX2 and PTX2 in positive ion LCMS analysis are shown in Fig. 2a,b. Within the samples from August 2003, only trace amounts of OA and PTX2 were found in 2 of the samples (the one from 26 August is shown in Fig. 2c,d) while only one showed a small amount of PTX2. This toxin (PTX2) was the only toxin detected in single- cell isolates of the co-occurring

Table 1. Phalacroma rotundatum and Dinophysis spp. Estimates of toxin content per cell (pg cell ${ }^{-1}$ ) in picked cells of $P$. rotundatum. Relative abundance (\%) of each Dinophysis species and of $P$. rotundatum in relation to the total number of toxic species (Dinophysis spp. + P. rotundatum). DTX2: dinophysistoxin-2; OA: okadaic acid; PTX2: pectenotoxin-2; nd: not detected

\begin{tabular}{|c|c|c|c|c|c|c|c|}
\hline $\begin{array}{l}\text { Sampling } \\
\text { date }\end{array}$ & $\begin{array}{l}\text { No. of } \\
\text { cells }\end{array}$ & $\begin{array}{c}\text { OA } \\
\left(\text { pg cell }^{-1}\right)\end{array}$ & $\begin{array}{c}\text { DTX2 } \\
\left(\text { pg cell }{ }^{-1}\right)\end{array}$ & $\begin{array}{c}\text { PTX2 } \\
\left(\text { pg cell }^{-1}\right)\end{array}$ & $\begin{array}{l}\text { Total toxin } \\
\left(\text { pg cell }{ }^{-1}\right)\end{array}$ & Cell appearance & $\begin{array}{c}\text { Relative abundance } \\
\qquad(\%)\end{array}$ \\
\hline $25 / 8 / 2003$ & 38 & nd & nd & 0.8 & 0.8 & $\begin{array}{l}\text { Normal appearance of } \\
\text { vegetative cells }\end{array}$ & $\begin{array}{l}\text { D. caudata }(66 \%) \\
\text { D. acuminata }(16 \%) \\
\text { P. rotundatum }(18 \%)\end{array}$ \\
\hline $25 / 8 / 2003$ & 40 & 0.3 & nd & 0.7 & 1.0 & $\begin{array}{l}\text { Normal appearance of } \\
\text { vegetative cells }\end{array}$ & $\begin{array}{l}\text { D. caudata }(66 \%) \\
D . \text { acuminata }(16 \%) \\
\text { P. rotundatum }(18 \%)\end{array}$ \\
\hline 26/8/2003 & 70 & nd & nd & nd & nd & $\begin{array}{l}\text { Small and pale } \\
\text { non-vacuolated cells }\end{array}$ & $\begin{array}{l}\text { D. caudata }(66 \%) \\
\text { D. acuminata }(16 \%) \\
\text { P. rotundatum }(18 \%)\end{array}$ \\
\hline 26/8/2003 & 50 & nd & nd & nd & nd & $\begin{array}{l}\text { Small and pale } \\
\text { non-vacuolated cells }\end{array}$ & $\begin{array}{l}D . \text { caudata }(66 \%) \\
D . \text { acuminata }(16 \%) \\
\text { P. rotundatum }(18 \%)\end{array}$ \\
\hline $26 / 8 / 2003$ & 66 & 0.5 & nd & 0.1 & 0.6 & $\begin{array}{l}\text { Small and pale } \\
\text { non-vacuolated cells }\end{array}$ & $\begin{array}{l}\text { D. caudata }(66 \%) \\
\text { D. acuminata }(16 \%) \\
\text { P. rotundatum }(18 \%)\end{array}$ \\
\hline $26 / 7 / 2005$ & 48 & nd & nd & nd & nd & $\begin{array}{l}\text { Normal appearance } \\
\text { of vegetative cells }\end{array}$ & $\begin{array}{l}\text { D. acuminata }(82 \%) \\
\text { P. rotundatum }(18 \%)\end{array}$ \\
\hline $26 / 9 / 2005$ & 51 & 0.7 & 0.9 & nd & 1.6 & $\begin{array}{l}\text { Normal appearance } \\
\text { of vegetative cells }\end{array}$ & $\begin{array}{l}\text { D. acuminata }(60 \%) \\
\text { P. rotundatum }(40 \%)\end{array}$ \\
\hline $17 / 4 / 2007$ & 142 & nd & nd & nd & nd & $\begin{array}{l}100 \% \text { vacuolated cells, } \\
\text { some showing orange } \\
\text { autofluorescence }\end{array}$ & $P$. rotundatum $(100 \%)$ \\
\hline $29 / 10 / 2007$ & 58 & nd & nd & nd & nd & $\begin{array}{l}\text { Vacuolated cells, some } \\
\text { showing orange } \\
\text { autofluorescence }\end{array}$ & $\begin{array}{l}\text { D. acuminata } \\
\text { D. acuta }\end{array}$ \\
\hline $29 / 10 / 2007$ & 52 & nd & nd & nd & nd & $\begin{array}{l}\text { Vacuolated cells, some } \\
\text { showing orange } \\
\text { autofluorescence }\end{array}$ & $\begin{array}{l}\text { D. acuminata } \\
\text { D. acuta }\end{array}$ \\
\hline $3 / 12 / 2007$ & 50 & nd & nd & nd & nd & $\begin{array}{l}\text { Normal appearance } \\
\text { of vegetative cells }\end{array}$ & P. rotundatum $(100 \%)$ \\
\hline
\end{tabular}



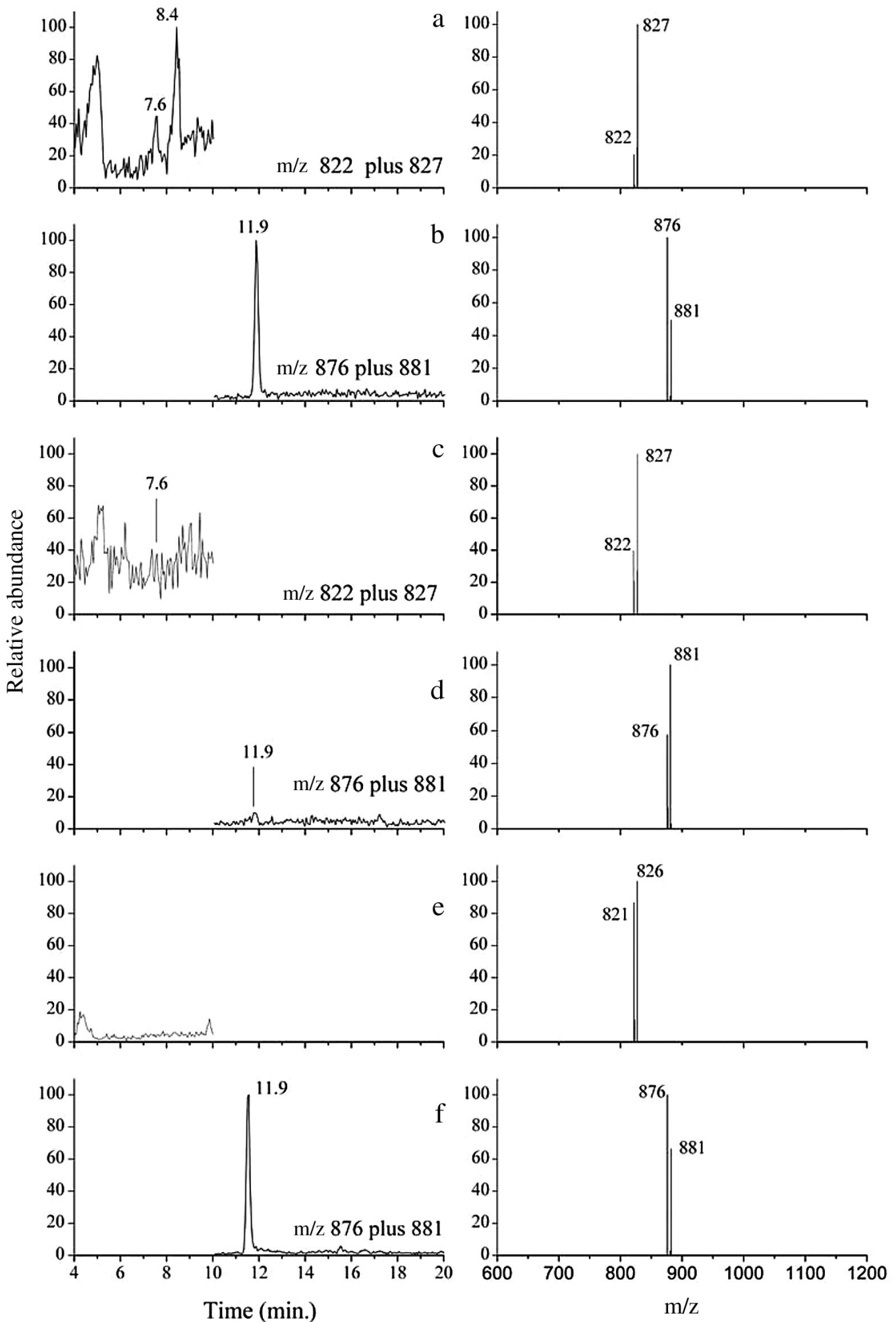

Fig. 2. Phalacroma rotundatum and Dinophysis caudata. Selected liquid chromatography-mass spectrometry (LC-MS) chromatograms (left) and mass spectra (right) obtained by selected ion monitoring (SIM) analysis, in positive ionization mode, for $\left[\mathrm{M}+\mathrm{NH}_{4}\right]^{+}$and $[\mathrm{M}+\mathrm{Na}]^{+}$ions of standards and of picked cells of P. rotundatum and D. caudata collected on 26 August 2003. (a) Okadaic acid (OA) (7.6 min) and dinophysistoxin-2 (DTX2) (8.4 min) standards with identical mass spectrum; (b) pectenotoxin-2 (PTX2) (11.9 min) standard; (c) OA (7.6 min) and (d) PTX2 (11.9 min) in picked cells of $P$. rotundatum; and (e) OA (not detected) and (f) PTX2 (11.9 min) in picked cells of D. caudata. m/z: mass to charge ratio 
D. caudata (Fig. 2e,f), which was the most abundant Dinophysis species, followed by $D$. acuminata that August (Table 1). Toxins were not detected in cells analyzed in July 2005, while cells from September 2005 showed low levels of OA $\left(0.7 \mathrm{pg} \mathrm{cell}^{-1}\right)$ and DTX2 $\left(0.9 \mathrm{pg} \mathrm{cell}^{-1}\right)$. OA is the only toxin found in Galician strains of D. acuminata (Blanco et al. 1995) - which in the present study was the predominant species of Dinophysis in the plankton concentrate in September 2005 - and DTX2 is an important component in the toxin profile of $D$. acuta (Pizarro et al. 2009), a species that was present in the Galician Rías from April to November 2005 (Escalera et al. 2010). Neither OA nor DTX2 or PTX2 were found in 4 samples from April, October, and December 2007. Three of these samples had a high proportion of vacuolated cells of $P$. rotundatum (Table 1), and in some of them, vacuoles exhibited DNA rests when stained with SYBR Green I and observed under epifluorescence using a blue filter set (Fig. 3a,b), as well as an intense orange autofluorescence when a filter specific for phycoerythrin was used

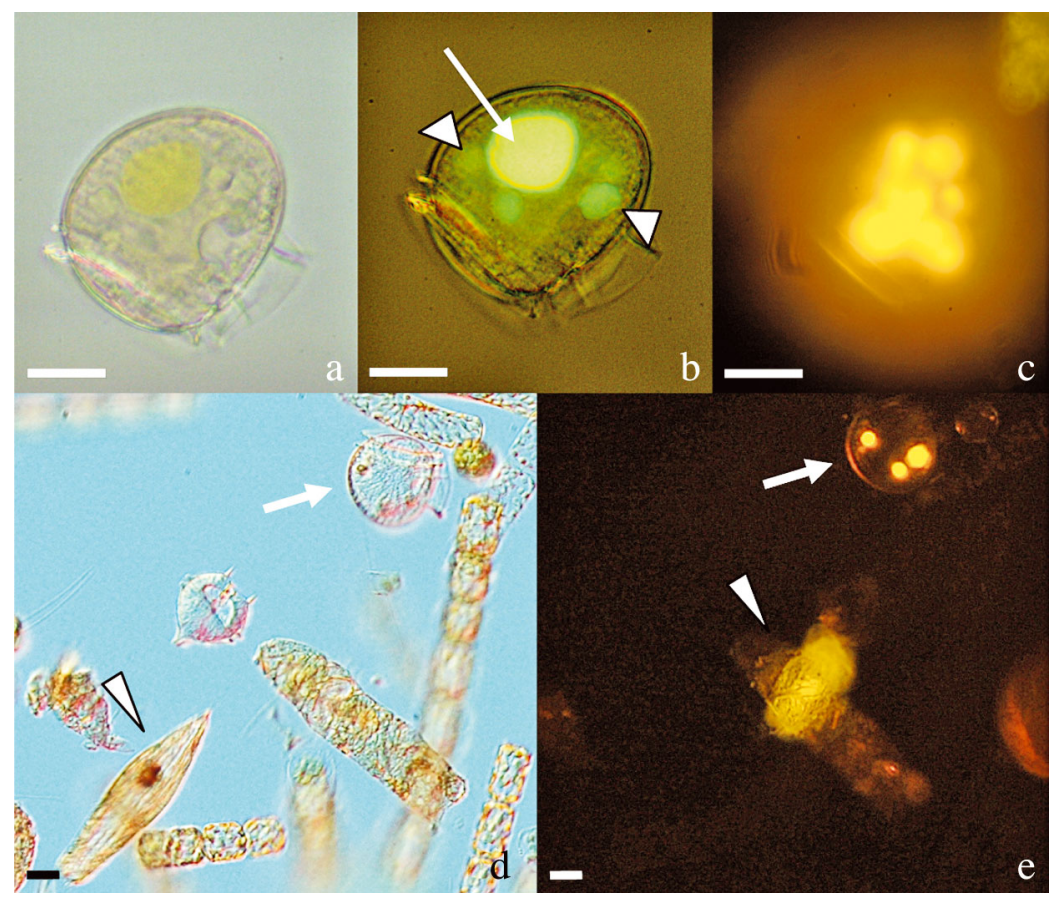

Fig. 3. Phalacroma rotundatum and Tiarina cf. fusus. Differential interference contrast (DIC) and epifluorescence micrographs of $P$. rotundatum specimens with digestive vacuoles. (a) DIC and (b) epifluorescence (excitation 450 to $490 \mathrm{~nm}$, emission $520 \mathrm{~nm}$ long-pass filter set) micrographs of a $P$. rotundatum cell stained with SYBR Green I (arrow: nucleus, arrowheads: vacuoles); (c) epifluorescence (excitation $546 \mathrm{~nm}$, emission $585 \mathrm{~nm}$ single-pass filter set, specific for phycoerithrin) micrograph of the same live P. rotundatum cell showing autofluorescent vacuoles; and (d) phase contrast and (e) epifluorescence (excitation $546 \mathrm{~nm}$, emission $585 \mathrm{~nm}$ single-pass filter set) micrograph of a live P. rotundatum (arrow) and an actively swimming T. cf. fusus (arrowhead). In (d) and (e), both specimens exhibited the same phycoerythrin-like autofluorescence; micrograph (e) was taken $0.5 \mathrm{~s}$ later than (d). Scale bars $=20 \mu \mathrm{m}$
(Fig. 3c,d). Further, in the samples from April and December 2007, in which toxins were not detected, $P$. rotundatum was the only potential toxin producer present in the plankton concentrate.

Previous studies showing the association of Phalacroma rotundatum with lipophilic toxins found in plankton hauls and shellfish are ambiguous. Vershinin \& Kamnev (2001) reported DSP toxins in mussels from the Black Sea when both $P$. rotundatum and Dinophysis caudata were present, so the species responsible for the outbreak could not be ascertained. anco et al. (1995), based on multiple regression alysis of toxin content (HPLC-FD analyses) in planknet hauls versus Dinophysis spp. cell counts, esticells of $P$ rotundatum that coincided with those pres in co-occurring cells of toxigenic Dinophysis spp. Cembella (1989) found OA in net hauls - analyzed with an enzymatic assay in addition to HPLC - where $D$. acuminata plus $D$. norvegica were prominent, but no traces of diarrhetic toxins were found in hauls rich in $P$. rotundatum from eastern Canada. Masselin et al. (1992) found a decrease in toxin content in hauls when maximum concentrations of $P$. rotundatum appeared in addition to frequent populations of $D$. cf. acuminata, which led them to suggest that French strains of the former were not toxic. Caroppo et al. (1999), using a toxicity test (Microtox system), did not detect toxicity either in plankton concentrates rich in $P$. rotundatum or in picked-cell samples obtained when the species reached a seasonal maximum density (1460 cells $\mathrm{l}^{-1}$ ).

In order to avoid analytical artefacts, all single-cell analyses in the present study were performed by LC-MS under identical chromatographic conditions. In all picked-cell samples of Phalacroma rotundatum in which lipophilic toxins were detected, the toxin profile mimicked that of co-occurring mixotrophic species of Dinophysis; samples of picked cells from plankton populations where $P$. rotundatum was the only potential lipophilic-toxin producer showed undetectable levels of toxins (Pizarro 2008). Cell-toxin content in $P$. rotundatum was extremely low whenever toxins were detected, and different toxin profiles were found for this species even in extracts of groups of 
cells isolated from the same plankton concentrate (Table 1). From these results we can conclude that, at least between 2003 and 2007, P. rotundatum from the Galician Rías did not make a relevant contribution to overall plankton toxicity and did not pose a threat of shellfish contamination with DSP toxins.

Bright red-orange digestive vacuoles are rarely observed in mixotrophic species of Dinophysis (Jacobson \& Andersen 1994), although Carvalho et al. (2008) found colorful vacuoles and cryptophyte-like bodies in the cytoplasm of $D$. norvegica cells from the Baltic Sea. Dinophysis species in culture do not feed directly on cryptophyte algae but can be grown successfully feeding the ciliate Myrionecta rubra that has previously been fed cryptophytes (Park et al. 2006). These cryptophyte plastids (hence the orange color) may remain active for $>10$ wk in M. rubra (Johnson et al. 2007). Similarly, D. caudata fed on $M$. rubra can also retain these plastids for a long period of time (Park et al. 2008), sometimes dispersed in the cytoplasm (Nagai et al. 2008) and not within vacuoles (García-Cuetos et al. 2010). A recent study verified the active uptake of plastids from $M$. rubra by $D$. caudata, which is clear evidence of kleptoplasty, but the possibility of some kind of semi-permanent plastids resident in $D$. caudata still cannot be excluded (Minnhagen et al. 2011).

Park \& Kim (2010) found bright-orange fluorescent inclusions in the mixotrophic dinoflagellate Fragilidium duplocampanaeforme that had recently ingested Dinophysis caudata and D. acuminata. Thus, it seems that mixotrophic dinoflagellates may emit brightorange autofluorescence from their ingested prey for a limited period of time. Observations in the present study constitute the first report of orange autofluorescence in digestive vacuoles of the heterotrophic dinoflagellate Phalacroma rotundatum. The same kind of orange autofluorescence was observed inside the lorica of the ciliate Tiarina cf. fusus (Fig. 3d,e), a potential prey of $P$. rotundatum, which was frequently observed co-occurring with $P$. rotundatum. These observations led us first to suggest the possibility that the orange autofluorescence in the digestive vacuoles of $P$. rotundatum were probably remains of mixotrophic species of Dinophysis taken up by Tiarina spp. ciliates that had previously fed on them, and that this transfer of Dinophysis spp. remains would explain the presence of toxins in $P$. rotundatum that mimicked those of co-occurring Dinophysis spp. Interestingly, picked cells of $P$. rotundatum with a high percentage of vacuolated cells that included observations of orange autofluorescence (samples from 2007 in Table 1) had no traces of toxins. It is unlikely-considering the myzocytotic preying behavior of $P$. rotundatum - that the orange autofluorescence in the vacuoles came from cryptophytes or cyanobacteria prey, i.e. the 2 groups of phycoerythrin-containing microalgae with no lipophilic toxins. Pelagic food webs are very complex and far from being understood completely (Jeong et al. 2002). The 2 possible interpretations of the orange-fluorescing vacuoles are that $P$. rotundatum either fed directly on phycoerythrin-containing Myrionecta rubra, or fed on tintinnids that had previously fed on M. rubra and still kept remains of its pigments in their digestive vacuoles.

To date, Phalacroma rotundatum and Protoperidinium crassipes are the only heterotrophic dinoflagellates reported to contain lipophilic shellfish toxins DSP and azaspiracids respectively - but toxin production in laboratory cultures of phototrophic and mixotrophic microalgae has been linked to photosynthesis (Granéli \& Flynn 2006, Kim et al. 2008). Recent findings showed that the small dinoflagellate Azadinium spinosum is the real producer of azaspiracids (Tillmann et al. 2009). Therefore, Protoperidinium crassipes $(>100 \mu \mathrm{m})$ acts as a vector of azaspiracid shellfish poisoning (AZP) toxins accumulated from the ingestion of small (10 to $15 \mu \mathrm{m}$ ) AZP-toxin producers.

Results from the present study lead us to propose that: (1) Phalacroma rotundatum acts as a vector of toxins produced by mixotrophic co-occurring species of Dinophysis that previously had been eaten by $P$. rotundatum's ciliate prey; and (2) orange autofluorescence in $P$. rotundatum vacuoles suggests that this species may include Myrionecta rubra as a prey organism. Conclusive testing of these hypotheses is now possible using laboratory cultures of $P$. rotundatum and M. rubra, and is the subject of ongoing investigations.

Acknowledgements. We thank the crew of RV 'J. M. Navaz' for their assistance at weekly samplings in the Galician Rías. DTX2-quantified reference material was kindly provided by P. Hess. This work was funded by EU projects HABIT (EU FP6 003932) and MIDTAL (EU 7FP 201724) and by national (MICINN, Spain) project TURDIRÍAS (CTM2006-13884-C0202/MAR).

\section{LITERATURE CITED}

Blanco J, Fernández M, Mariño J, Reguera B and others (1995) From Dinophysis spp. toxicity to DSP outbreaks: a preliminary model of toxin accumulation in mussels. In: Lassus P, Arzul G, Erard Le Denn E, Gentien P, Marcaillou-Le Baut (eds) Harmful marine algal blooms. Lavoisier, Intercept, Paris, p 777-782

Caroppo C, Congestri R, Bruno M (1999) On the presence of Phalacroma rotundatum in the southern Adriatic Sea (Italy). Aquat Microb Ecol 17:301-310

Carvalho WF, Minnhagen S, Granéli E (2008) Dinophysis norvegica (Dinophyceae), more a predator than a producer? Harmful Algae 7:174-183

$>$ Cembella AD (1989) Occurrence of okadaic acid, a major diarrheic shellfish toxin, in natural populations of Dinoph- 
ysis spp. from the eastern coast of North America. J Appl Phycol 1:307-310

Elbrächter M (1991) Faeces production by dinoflagellates and other small flagellates. Mar Microb Food Webs 5: 189-204

Escalera L, Moita T, Moroño A, Cerejo M, Cabanas JM, RuizVillareal M, Reguera B (2010) Bloom dynamics of Dinophysis acuta in an upwelling system: in situ growth versus transport. Harmful Algae 9:312-322

García-Cuetos L, Moestrup Ø, Hansen PJ, Daugbjerg N (2010) The toxic dinoflagellate Dinophysis acuminata harbors permanent chloroplasts of cryptomonad origin, not kleptochloroplasts. Harmful Algae 9:25-38

Granéli E, Flynn KJ (2006) Chemical and physical factors influencing toxin content. In: Granéli E, Turner J (eds) Ecology of harmful algae. Ecological Studies 189. Springer-Verlag, Berlin, p 229-241

Hallegraeff GM, Lucas IAN (1988) The marine dinoflagellate genus Dinophysis (Dinophyceae): photosynthetic, neritic and non-photosynthetic, oceanic species. Phycologia 27: 25-42

Hansen PJ (1991) Dinophysis - a planktonic dinoflagellate genus which can act both as a prey and a predator of a ciliate. Mar Ecol Prog Ser 69:201-204

> Jacobson DM, Andersen RA (1994) The discovery of mixotrophy in photosynthetic species of Dinophysis: light and electron microscopic observations of food vacuoles in Dinophysis acuminata, D. norvegica and 2 heterotrophic dinophysioid dinoflagellates. Phycologia 33: 97-100

> Jensen MH, Daugbjerg N (2009) Molecular phylogeny of selected species of the order Dinophysiales (Dinophyceae) - testing the hypothesis of a dinophysioid radiation. J Phycol 45:1136-1152

Jeong HJ, Yoon JY, Kim JS, Yoo YD, Seong KA (2002) Growth and grazing rates of the prostomatid ciliate Tiarina fusus on red-tide and toxic algae. Aquat Microb Ecol 28: 289-297

Johnson MD, Oldach D, Delwiche CF, Stoecker DK (2007) Retention of transcriptionally active crytophyte nuclei by the ciliate Myrionecta rubra. Nature 445:426-428

Kamiyama T, Suzuki T (2009) Production of dinophysistoxin-1 and pectenotoxin-2 by a culture of Dinophysis acuminata. Harmful Algae 8:312-317

Kim S, Kang YG, Kim HS, Yih W, Coats DW, Park MG (2008) Growth and grazing responses of the mixotrophic dinoflagellate Dinophysis acuminata as functions of light intensity and prey concentration. Aquat Microb Ecol 51: 301-310

Larsen J, Moestrup Ø (1992) Potencially toxic phytoplankton. 2. Genus Dinophysis (Dinophyceae). In: Lindley JA (ed) ICES identification leaflets for plankton. International Council for the Exploration of the Sea (ICES), Leaflet $\mathrm{N}^{\circ}$ 180, Plymouth Marine Laboratory, Plymouth, p 1-2
Lee JS, Igarashi TT, Fraga S, Dahl E, Hovgaard P, Yasumoto T (1989) Determination of diarrhetic toxis in various dinoflagellate species. J Appl Phycol 1:147-150

Masselin P, Lassus P, Bardouil M (1992) High performance liquid chromatography analysis of diarrhetic toxins in Dinophysis spp. from the French coast. J Appl Phycol 4:385-389

Miles CO, Wilkins AL, Samdal IA, Sandvik M and others (2004) A novel pectenotoxin, PTX-12, in Dinophysis spp., and shellfish from Norway. Chem Res Toxicol 17: 1423-1432

Minnhagen S, Kim M, Salomon PS, Yih W, Granéli E, Park MG (2011) Active uptake of kleptoplastids by Dinophysis caudata from its ciliate prey Myrionecta rubra. Aquat Microb Ecol 62:99-108

> Nagai S, Nishitani G, Tomaru Y, Sakiyama S, Baba K, Kamiyama T (2008) Predation by the toxic dinoflagellate Dinophysis fortii on the ciliate Myrionecta rubra and observation of sequestration of ciliate chloroplasts. J Phycol 44:909-922

> Park MG, Kim M (2010) Prey specificity and feeding of the thecate mixotrophic dinoflagellate Fragilidium duplocampanaeforme. J Phycol 46:424-432

Park MG, Kim S, Kim HS, Myung G, Kang YG, Yih W (2006) First successful culture of the marine dinoflagellate Dinophysis acuminata. Aquat Microb Ecol 45:101-106

Park MG, Park JS, Kim M, Yih W (2008) Plastid dynamics during survival of Dinophysis caudata without its ciliate prey. J Phycol 44:1154-1163

Pizarro G (2008) Estudio, mediante LC-MS, de la variabilidad del perfil y contenido de toxinas, en poblaciones de Dinophysis spp. agentes de episodios DSP en las Rías Baixas Gallegas. PhD dissertation, University of Vigo

> Pizarro G, Paz B, González-Gil S, Franco JM, Reguera B (2009) Seasonal variability of lipophilic toxins during a Dinophysis acuta bloom in Western Iberia: differences between picked cells and plankton concentrates. Harmful Algae 8:926-937

Suzuki T, Miyazono A, Baba K, Sugawara R, Kamiyama T (2009) LC-MS/MS analysis of okadaic acid analogues and other lipophilic toxins in single-cell isolates of several Dinophysis species collected in Hokkaido, Japan. Harmful Algae 8:233-238

Tillmann U, Elbrächter M, Krock B, John U, Cembella AD (2009) Azadinium spinosum gen. et sp. nov. (Dinophyceae) identified as a primary producer of azaspiracid toxins. J Phycol 44:63-79

Vershnin A, Kamnev A (2001) Harmful algae in Russian European coastal waters. In: Hallegraeff GM, Blackburn SI, Bolch CJ, Lewis RJ (eds) Harmful algal blooms. IOCUNESCO, Paris, p 112-114

Zingone A, Larsen J (2011) Dinophysiales. In: Moestrup Ø et al. (eds) IOC-UNESCO taxonomic reference list of harmful micro algae. Available at: www.marinespecies.org/HAB

Submitted: September 2, 2010; Accepted: May 30, 2011

Proofs received from author(s): July 24, 2011
Editorial responsibility: Patricia Glibert, Cambridge, Maryland, USA 